MARKETING AND BRANDING
RESEARCH

\title{
Digital marketing planning with the brand dashboard approach
}

\author{
Alptekin Erkollar, Birgit Oberer* \\ Sakarya University, Sakarya Business School, Sakarya, Turkey
}

\begin{abstract}
Keywords:

Brand, Dashboard, Brand Index, Master Brand

Correspondence:

birgit.oberer@gmail.com

A brand is a name, a symbol, a term or a design which identifies an organizations goods and services as distinct from those of other organizations. Brands support customers in their decision making processes and add to an organization's reputation. Branding is the process of providing goods and services with the power of a brand. It is the communication of values, attributes, and characteristics of goods and services, clarifying what a particular brand is. In this study a multidimensional brand dashboard was developed and implemented in a company operating the plastics industry in Europe, focusing on three main markets, namely packaging, automotive, and building and construction, launching one master brand and three sub brands on the different markets. Objectives of the project were to deliver better brand briefs, get a greater visibility of projects in the pipeline and improve the master brand / sub brand management portfolio, with a series of indicators which are applied such as accuracy of branded materials, on time delivery, preservation of brand values, and equity. The results of the study revealed that within the one year pilot phase, the values of the main indicators including brand development index and brand equity improved significantly. Newly implemented indicators such as brand influence rate, brand cross index and brand penetration index have all values within predefined ranges. Generally, the brand management portfolio could be improved in terms of master brand /sub brand matrix levels and accuracy of brand materials.
\end{abstract}

(C)AIMI Journals

\section{Introduction}

Kolter (1994) defined brand as a name, term, sign, symbol or design, or a mixture of them intended to recognize the goods or services of one seller or group of sellers and to distinguish them from those of competitors. Generally, the term branding stands for creating a brand itself as well as a brand identity for differentiating products and services. Brand management 
includes all activities along the brand life cycle such as brand creation, cost management, shareholder and stakeholder analysis, financial activities, customer focused brand marketing, brand innovation, and brand communication (Erkollar \& Oberer, 2013a; Erkollar \& Oberer, 2010b).

Companies use social media to get in touch with their customers, attracting them to buy a specific product, to become aware of a specific brand or to post comments on a brand on different social media. Instead of just getting the customer's attention in order to deliver a message or to provoke a response, effective social media marketing needs listening, understanding, and some kind of customer participation to create added value and to build up business relations. For starting social media marketing, a marketing plan is necessary in order to follow a structured process (Burke, 2006; Stobbe \& Jüch, 2005). Generally, such a marketing plan can be divided into five parts, which are research, create, share, discuss, and improve. 'Research' means an ongoing process on market research, gathering information about the industry, customers, products, services, competitors, and current trends influencing the behavior of a company's stakeholders. 'Create' stands for creating content and establishing online conversations about a company, its brand, products, services, customer incentives, green IT initiatives, stakeholder management, and promotions. The creation of an added value should be in the center of a company's activities. To 'share' means sharing the content created to market a company's business mainly indirectly. With social media new elements are added to the traditional marketing mix: using social networks or blogs to post some comments on the company's recently launched product and spread selected comment to a greater audience (Blanchard \& Markus, 2004; De Moor \& Weigand, 2007). In general, because of this indirect promotional strategy, this one should be more effective than a direct advertising or promotion campaign that customers are bored of. 'Discuss' means the more followers that a company has the higher the need for vocalizing appreciation, thoughts and opinions, both positive and negative ones (Erkollar \& Oberer, 2013b; Mao, 2010).

Social media can be used to give followers the feeling of being valuable for the company. 'Improving' means developed structures have to be evaluated over time whether being appropriated or not. Social media are one way to contact customers and to get in touch with the company's environment; so, if the environment is volatile, the ways of reaching the audience should be at least partly volatile as well to give a company the flexibility needed to adapt to the changing environmental conditions. Maybe the use of one type of social media as a channel to reach customers was perfect at a given moment but because of changing customer preferences, a move in terms of technology or target grouping makes this channel unnecessary and a new, possibly innovative one waits for a company to be examined and adopted for social media use. This continuous process can be summarized in the 'improve' step of the social media marketing process (Bagozzi \& Dholakia, 2002; Gammelgaar, 2010; Lefebvre, 2007; Mohmed \& Rahman, 2010).

Social media marketing can also be used as a market research tool, as companies can learn about customer demographics, preferences, and behavior, find niche markets and learn about competitors (Moisescu, 2009). Social media marketing offers companies an opportunity to communicate their brand message to a wider audience: People should hear about the brand (brand awareness), recognition processes should be initialized (people hear the name of a 
brand and remember what they have heard before and in the longer run should remember the business run behind the recognized brand and are able to talk to others about the company's brand and business case). With social media marketing an online reputation management of companies can be developed and treated. Social media measurement means measuring the effectiveness of social media. The basic difficulty for companies measuring their social media initiatives is finding certain metrics for the measurement (Goncharuk, 2011; McDonald, de Chernatony, \& Harris 2001). To measure the success of a social media campaign companies can check metrics such as gross views (the number of times users are exposed to a brand through selected social media channels), connections (calculating the interest in the company's brand or company with tracking subscribers to blogs, social networks followers or group members) or the audience engagement (checking how active the audience is engaging with a brand). Social media marketing can contribute to a more active relationship between a company and its customers to create an intense awareness of products or brands and to strengthen long-term business relations and increase customer loyalty (Czinkota \& Ronkainen, 2007; Ferreira \& Armagon, 2011; Khraim, 2011). Central for a brand strategy is the brand portfolio management, the ability to organize all the company's brands in these portfolios. This is crucial for every company that has more than one brand (Erkollar \& Oberer, 2010).

Brand equity is the expression of a brand's value or strength, describing a brand and measuring its total value. Benefits associated to brand equity are strong market share, customer loyalty, improved profitability, and less vulnerability to competitor activities. A brand strategy is a plan for how a company will support its business strategy by building relationships with customers (Erkollar \& Oberer, 2013b).

A brand strategy is a long run strategic plan for the development of a brand to meet some brand related to predefined targets, with a brand strategy consisting of some relevant components which are summarized below.

Purpose: Every brand has to define a purpose, not just a promise being different to other brands. A brand purpose is derived from a corporate one, which equals the companies corporate strategies and has to be aligned with these. The key driver is the business purpose defined for the organization. To define this purpose, there are two different approaches. One of them is the functional approach which focuses on the evaluations of success in terms of immediate and commercial reasons. The other one refers to an intentional approach which focuses on success as it relates to the ability to make money and contribute to the world's welfare. There are a plenty of examples of companies not only offering their products but having the willingness to improve their customers (daily) life such as furniture sellers, marketing their own importance of 'creating a better everyday life'.

Consistency: All elements of a brand have to be consistent, which means potential customers have to see a message that the brand on all its platforms stands for, with all messages being cohesive.

Emotion: Customers are not always rational. In case, customers are brand loyal that they follow and an internal emotional voice tell them to buy exactly this branded product and not 
another one. These emotional decisions made by customers have to be considered actively in any kind of branding strategy a company might focus on.

Flexibility: In companies confronted with globalization, emerging markets, and changing technology related and business related environments, marketers have to stay flexible to adopt their behavior to some volatile market structures and changing environments. Doing that, companies have to focus on a strategic balance between their established brands and trends related adaptations, short run hypes, and competitive situations.

Employee Involvement: Employees have to be well trained that how to communicate the brand to customers. To ensure that, all brand companies and some bigger ones dedicate entire departments ensuring that the communication for all brands across all digital and human centered interactions remain consistent.

Loyalty: Companies have to create an environment to cause customers love their brand. Rewarding customers for their loyalty has to be cultivated. Providing social media recognition expresses that social media is the perfect channel to spread the customer love. Companies should respond to positive mentions of their brand and products in social media, retweet customers' tweets of things they care about or successes they have had, and show appreciation for the love customers spread about the company. Using social media to recognize customer success, happiness, and interests is a great and easy way to show customers a company cares about them.

Regarding solicit feedback, companies should ask their customers for feedback on products/services, marketing content, user experience, and customer service. Some other ways to 'give and get customer love are provide stellar customer service/support, offering guest blogging opportunities, providing complementary products for customers that complement their own choice. This might show customers that a company cares about them and their aim is not just selling stuff. In the same line of the argument, companies should say thank you whenever they have an opportunity since their customers have chosen their products/services and did not transfer to some competitors. Considering competitive awareness, companies should take competition as a challenge to improve the company's own strategy and create a greater value in their overall brand.

Digital marketing summarizes activities used for promoting products or brands via different forms of electronic media. Challenges digital marketers face are an intensifying competition, exploding data volumes, and development of several digital channels. What makes a digital marketer successful? They are able to respond to and interact with customers who are increasingly independent, dynamic with a nearly full knowledge on products and brands. They have the ability to manage complex customer relationships in and across different channels, focusing on the traditional way and the digital one. Successful digital marketers are able to handle huge amounts of data (big data) to initiate a faster decision making process. Brand management is responsible for monitoring, measuring and managing brand equity, increasing brand awareness, driving brand understanding within the organization, managing brand identity consistency, and helping to develop new brands and sub brands. The main objectives of this paper are to determine which factors are integral parts 
of brand management practice, to determine how these factors affect the performance of a brand, to determine how master brand/sub brand relationships have to be handled in a multi brand company and to analyze if a brand dashboard could improve brand performance.

\section{The Literature Review}

Digital marketing refers to a form of marketing that circulates information in digital format which can be characterized as computers, smart phones, or any form of digital devices for promoting the brand image, delivering the message of the brand, and increasing the sales through advertising of the product. A brand helps to establish a unique company identity and appearance in turn enabling the company to attract their target customers for repeating purchases and attracting their interest in long-run business relations (Erkollar \& Oberer, 2010; Ghachem, 2011). The digital marketing department that advances marketing promotions based on a calendar has an aim of achieving a successful online sales campaign. Consistent brand messages encourage target groups and start the development of long run oriented business relations (Duduciuc \& Ivan, 2014; Erkollar \& Oberer, 2010; Grigore, Florica, \& Catalina, 2010; Lakeworth, 2008). The main purpose of the brand awareness side is to build a brand image in the eyes of the customer through creative online advertisements. The sales of the products come secondary. In other words, it aims to make consumer understand the brand and internalize the brand image as if it is part of the self. In order to customize the brand, the brand awareness team engage in various channels to reach to the luxury customers. In order to survive, manufacturers have to consider the upcoming short run and longer run market trends that will influence their industry and have an impact on brand performance and the management of their brands (Abdullah \& Hasliza, 2011; Izadi Manesh \& Hozouri, 2013). The main aim in this form of marketing is to reach to the main customer segment of the brand through the website, where the targeted customer have traffic. This form of marketing is much preferable when the website that display the ad of the brand has a similar content. In other words, if the website that affiliates has a similar content with the ad owner, then the customer can be more curious on the content of the advertiser (Mousavi, Far, Shahrokh, \& Taghavifard, 2013; Story \& Hess, 2010; Wong \& Merrilees, 2008). Brand name of a product is outcome of the marketing effects or outcomes in comparison with those that would have been build up if same product was considered without that respective brand name. To be able to establish a performance management for brands, the brand performance scorecard can be used as a main source in the strategic dimension as well as in the operational one. There are various methods of data collection focusing on factors such as nature, scope and object of inquiry, availability of funds, time factor, and the precision required. The authors focused on primary research as well as on the case study method. The data collection process of this study consists of two approaches, namely a content analysis of research articles already published by the authors and other researchers and a case study analysis. The case study method is a very popular form of qualitative analysis.

The RACE Digital Marketing Planning Framework stands for Reach $<$ Act $<$ Convert $<$ Engage. It summarizes the key online marketing activities that need to be managed as part of digital marketing and covers the full customer lifecycle or marketing funnel.

RACE KPIs are summarized below. 


\section{REACH:}

Awareness and visits (n searches, \% brand)

Volume: unique visitors

Quality: Bounce rate

Value: revenue per visit

\section{ACT:}

Interaction and leads (page views / visit)

Volume: $n$ leads

Quality: \% conversion to lead

Value: goal value per visit

\section{CONVERT:}

sales and profit (average order value)

Volume: n sales

Quality: \% conversion to sales

Value: Sales value

\section{ENGAGE:}

Loyalty and advocacy (n brand mentions)

Volume: \% of active customers

Quality: \% customer conversion

Value: \% of existing sales value

Marketing actions to be managed with RACE:

1. Key digital strategies: How do we want to grow our online business?

Reach: prospects and customers

Act: Achieve interaction

Convert: to lead or sale

Engage: through time

2. Marketplace analysis: How well are we using digital media now?

Audience and customer analysis

Competitor benchmarking

Online partner analysis

SWOT analysis

3. Objective setting: Which goals and KPIs should we use?

Vision and mission setting

Goal setting and evaluation

Google analytics

Managing digital marketing

4. Strategy: How can we achieve our goals?

Segmentation and targeting 
Brand positioning and value proposition

Engagement and content strategy

Integrated communication strategy

5. Tactics: Which digital marketing activities do we optimize?

Reach: Search Engine Optimization, pay per click, affiliate and partner marketing, online advertising, online PR, social media marketing

Act \& Convert: Conversion rate optimization, lead generation techniques, eCommerce management, home page optimization, landing page optimization

Engage: Content marketing, E contact strategy,customer service and support, mobile marketing, social CRM

\section{The Study}

There must be a balance between brand awareness and e-commerce (performance marketing) to create the image of the brand as well as raising the revenue. In a strategic brand management process basically four steps have to be included, namely identifying and establishing a brand, planning and implementing a brand marketing program, measuring and interpreting brand performance, and brand equity. Nowadays, companies are aware of the importance of branding for becoming and remaining competitive. Having one single brand, companies have learned how to handle the management of this brand. In the current study, a multidimensional dashboard (4-level approach) for multi brand companies is developed. The developed brand dashboard should affect positively the following dimensions including brand equity, monitoring, brand awareness_external and brand awareness_internal.

\section{Research Questions}

Based on the overall objective of the study, we have defined our main research questions as follows:

- $\mathrm{RQ}_{1}$ : Which dimensions have to be included in a brand performance dashboard?

- $\mathrm{RQ}_{2}$ : Could a 4-level brand performance dashboard be applied for a multi brand company?

\section{Method}

This study is a combination of library research and field research. Based on the authors' previous works and a document analysis on brand management, a framework for a multi brand dashboard was developed. A field research was conducted applying a non-participant direct observation method by implementing the developed dashboard in a company and analyzing the impact factors for the company's brand management process.

\section{Model Development}

Applying the RACE framework to create a dashboard contains several steps, summarized below.

KPIs for Stage 1: REACH

Analog marketing:

$<$ advertising $<<$ KPIs $>>$ impressions, response rate, cost per conversion

$<$ direct mail $<<$ KPIs $>>$ delivery rate, response rate, cost per conversion 
$<$ events $<<$ KPIs $>>$ registration, attendees, satisfaction

$<$ public \& media relations $<<$ KPIs $>>$ new releases, interviews, coverage, positive mentions, share of voice

Digital marketing:

$<$ website \& blog $<<$ KPIs $>>$ SEO efficiency, pay per click advertising efficiency

$<$ webinars $<<$ KPIs $>>$ attendee rate, drop off rate, conversion rate

$<$ social media $<<$ KPIs $>>$ connections

KPIs for Stage 2: ACT

Analog marketing

$<$ inbound phone calls

Digital Marketing

$<$ website \& blog $<<$ KPIs $>>$ subscribers, back links, time on site, downloads

$<$ social media $<<$ KPIs $>>$ engagement, sentiment, conversions

$<$ leads $<<$ KPIs $>>$ quality, conversions

KPIs for Stage 3: CONVERT

KPIs stage 1, 2 + the following

Digital marketing:

$<$ website and blog $<<$ KPIs $>>$ return visitors, eCommerce transactions

$<$ leads $<<$ KPIs $>>$ cost per lead

$<$ orders $<<$ KPIs $>>$ revenue from purchases, average order value

KPIs for Stage 4: ENGAGE

KPIs stage 1, 2,3 + the following

Digital Marketing:

$<$ website \& blog

$<<$ email $<<$ KPIs $>>$ open rate, click through rate, bounce rate, unsubscribe rate

$<$ social media $<<$ customer advocacy

$<$ orders

$<<$ revenue from repeat purchases

ROI

$<$ all marketing campaigns and initiatives

$<$ customer lifetime value

The brand dashboard focuses on the dimensions including stakeholder, market segment, media sources, and the internal dimension. These dimensions are matched with the RACE framework (reach, act, convert, engage) with the matrix introduced in Table 1 as the main structure of the brand dashboard.

Table 1 shows the brand dashboard structure withRACE dimentions. 
Table 1

Brand Dashboard Structure with RACE Dimensions

\begin{tabular}{|c|c|c|c|c|}
\hline Race Dimension & Brand Dimension & Volume & Quality & Value \\
\hline \multirow{3}{*}{ Reach } & Stakeholder & Unique Visitors & Bounce Rate & Revenue Per Visit \\
\hline & Market Segment & Unique Visitors/ Segment & Bounce Rate & Revenue Per Visit \\
\hline & Media Sources & Unique Visitors & Bounce Rate & Revenue Per Visit \\
\hline \multirow{4}{*}{ Act } & Stakeholder & n Leads & \% Conversion to Lead & Goal Value Per Visit \\
\hline & Market Segment & n Leads/ Segment & \% Conversion to Lead & Goal Value Per Segment \\
\hline & Media Sources & n Leads/ Segment & \% Conversion to Lead & Goal Value Per Segment \\
\hline & Internal Dimension & n Leads Analysis & \% Conversion to Lead & Goal Value Analysis \\
\hline \multirow{3}{*}{ Convert } & Stakeholder & n Sales & \% Conversion to Sales & Sales Value \\
\hline & Media Sources & n Sales & \% Conversion to Sales & Sales Value \\
\hline & Internal Dimension & n Sales & \% Conversion to Sales & Sales Value \\
\hline \multirow{3}{*}{ Engage } & Stakeholder & $\%$ of Active Customers & \% Customer Conversion & \% of Existing Sales Value \\
\hline & Media Sources & $\%$ of Active Customers & \% Customer Conversion & $\%$ of Existing Sales Value \\
\hline & Internal Dimension & $\%$ of Active Customers & \% Customer Conversion & $\%$ of Existing Sales Value \\
\hline
\end{tabular}

The main aim in this form of marketing is to reach to the main customer segment of the brand through the website, where the targeted customer have traffic. With the brand dashboard, applying the RACE framework, a model for evaluating the strategic brand management process should be developed. The multidimensional brand performance dashboard, introduced in this publication, is based on a brand performance scorecard model expanded by the authors in 2011 for a company concentrating on international multidimensional branding and the literature review done on brand management. A brand performance dashboard follows the idea of the balanced scorecard, defining different dimensions, key objectives, actions to be taken, performance indicators, and metrics as well as time frames. Table 2 depicts the four level structure of the brand performance dashboard filled with sample objectives, dimensions, and performance indicators for brand performance measurement. Level 1 shows the basic structure, objectives, dimensions, key performance indicators, time frame, priorities. Level 2 shows the dimensions combined with related categories for each. Level 3 contains an impact analysis focusing on the dimensions, namely brand, master brand, impact, and brand dimension. Table 2 gives an overview of the first level dashboard structure filled with some sample data. In this view, the basics of a single-brand performance dashboard are considered. Objectives are defined and prioritized and related dimensions such as customer related, process related or staff related added. The aspects including stakeholders, market segments, internal dimension, as well as media sources are explained and divided into further sub-categories and for every sub-dimension, dominant objectives are defined and key performance indicators are added which permit for the measurement of the defined targets. Furthermore, time frames as well as comments can be added and priority rules are used to select issues of the highest priority before the minor ones. For the targets added in the section performance indicator, references to other dimensions or sub-dimensions that the current one is related to can be added as well. With this functionality it is possible to get a first overview about the independence of different dimensions. For all 
key performance indicators, measures have to be defined. The same has to be done for all the other dimensions as well. The same is valid for the added further dimensions. Table 2 presents the level 1 Dashboard, basic structure (filled with sample data).

Table 2

Level 1 Dashboard, Basic Structure (Filled with Sample Data)

\begin{tabular}{llll}
\hline Dimensions & KPI & Time Frame & Priority \\
\hline Stakeholder_Consumer & $\begin{array}{l}\text { Use Satisfaction Surveys, Calculate } \\
\text { Customer Satisfaction Index (CSI) } \\
\text { \% Brand Sources, Converted to Brand } \\
\text { Items }\end{array}$ & Results Q2 & Priority: 2 \\
Priority: 1
\end{tabular}

Note. $\mathrm{Q}=$ quarter of the year [Q1-Q4] priority: 1-5 (1= lowest priority, 5= highest priority)

Sample objectives include improving brand awareness among media sources; establishing a benchmark system for customer satisfaction, brand preferences and loyalty, and awareness, distinguishing different market segments and their corresponding brand behavior; and increasing the brand awareness of brand attributes among key persons with direct customer contact. The structure for handling the master brand and its sub-brands is as follows: if there is an impact of the master brand on every single sub-brand, it needs to be indicated. In Table 3 this structure is shown in a level 2 dashboard template. Table 3 represents the level 2 brand performance dashboard (template to be filled).

Table 3

Level 2. Brand Performance Dashboard (Template to be Filled)

\begin{tabular}{lll}
\hline Dimension & Related Category & Impact Analysis (IA) \\
\hline Customer & Category $<$ to be selected $>$ & $<$ open impact analysis $>$ \\
& & $<$ IA / dimension $>$ \\
& & $<$ IA / category $>$ \\
Market Segment & Category $<$ to be selected $>$ & $<$ iA $/$ dimension $>$ \\
& & $<$ IA / category $>$ \\
\hline
\end{tabular}


Table 4 indicates a level 2 dashboard template filled with sample relational data.

Table 4

Level 2. Brand Performance Dashboard (Filled with Sample Data)

\begin{tabular}{ll}
\hline Dimension & Related Category \\
\hline Customer \% Customer_Current & Market Segment_Current
\end{tabular}

Table 5 exhibits the level 3 impact analysis_Brand_Dashboard - master brand (extract).

Table 5

Level 3. Impact Analysis_Brand_Dashboard - Master Brand (Extract)

\begin{tabular}{lll}
\hline Sub Brand System & Impact/ Dimension & Impact / Detail \\
\hline Sub Brand 3 [Name] & $\begin{array}{l}\text { Dimension 1: YES/NO } \\
\text { Dimension 2: YES/NO }\end{array}$ & $\begin{array}{l}\text { The icon indicates there is one more } \\
\text { dimension (dimension 3.1) in which a } \\
\text { detailed impact analysis on the sub brand } \\
\text { system and the different dimensions can } \\
\text { be done. A detailed analysis on dimension } \\
3.1 \text { is out of scope for this study, that is } \\
\text { why a placeholder is added. }\end{array}$ \\
\hline
\end{tabular}

\section{Results}

The sample company is the act of separating a global telecommunication operator and delivering a combination of information technology and communication services to more than 23.000 organizations, institutions, and private households worldwide. The company has one master brand 'AA' and five sub-brands AA.1, AA.2, AA.3, AA.4, and AA.5 and all of them are related somehow. Marketing activities on 'AA' have direct and indirect impacts on all sub 
brands. Branding decisions on a single sub brand might have an impact on the other sub brands and has an influence on the brand management of the master brand. The company had an active and functional brand management, but this only concentrated on the master brand. For sub brands, some marketing activities were organized but these were not aligned with the master brand management and sometimes impacts from AA.1 brand related activities had direct effects on other sub brands which was not taken into account at all. With the implementation of the brand management dashboard the management of the company also increased its strategic brand management process from the master brand to all sub brands. Master brand and sub brand relationships were considered and organized in a structured way. Before the dashboard was implemented the company had a working system of basic key performance indicators (KPIs) used to analyze the performance of the brand management. This system was extended within the project. Objective of the project was to establish an internal communication hierarchy and get a greater visibility of brand (marketing) projects in the pipeline.

\section{Dimensions to be Included in a Brand Performance Dashboard (RQ1)}

Based on the previously developed brand scorecard, literature review, and a conducted content analysis, the authors developed the performance dashboard containing four main dimensions including stakeholders, market segment, media sources, and an internal dimension. For each dimension related sub dimensions are developed. The developed structure is shown below in some selected sample relationships.

LEVEL 1: Dimension => sub dimension $1+$ sub dimension $2+$ sub dimension $n$ Stakeholder $=>$ stakeholder_customer + stakeholder_employee + stakeholder_interest group Stakeholder_customer => customer_current + customer_prospective + customer_former

LEVEL 2: Dimension=>related category1 + related category $2+$ related category $n$ Customer_current $=>$ market segment current + media sources_sponsoring + internal_staff_sales

LEVEL 3: master brand $=>$ sub brand 1 => impact dimension 1 => impact dimension $2=>$ indicates 'next' level + indicates 'same' level

\section{Implementation of a 4-Level Brand Performance Dashboard in a Multi Brand Company (RQ2)}

After the dashboard implementation the following key performance indicators were tracked: Spend/flexible packing, project duration dime (PDT), rework (RW) cycles, time performance, incoming errors (IE), throughput errors (THE), output errors (OE). The dashboard results were compared with the company performance before the dashboard implementation, based on the following indicators. Some general indicators (brand development index (BDI), brand equity, close rate) were already in use, but with the dashboard implementation a set of new indicators, containing brand penetration, master brand influence rate, sub brand sales rate, press coverage, stakeholder value, employee index, customer index, and brand cross index was implemented as well. The evaluation of the brand management process with the dashboard applied and the new set of indicators implemented gives after one year in use the following results for 
I) indicators already in use: close rate: $8 / 11$; brand equity: $0.245 / 0.435$; brand development index(100): 1.2/1.8;

II) indicators implemented with the dashboard: Stakeholder value: 212, Master brand influence rate [0.01-0.09]: 0.05; Brand cross index [0.03-0.08]: 0.053, Brand penetration index: 1.0912; Sub brand sales rate [100-843]: 433, Employee index: 55\%, Market penetration index: 1.09 , Customer index: $87 \%$

\section{Discussion and Conclusion}

Brand plays an important role in product development and it is always necessary to find important factors influencing brand for different purposes such as gaining more market share and customer retention.

With the brand performance dashboard introduced in this study, brands themselves, brand dimensions and the corresponding brand environment can be analyzed. In level 1 brand objectives, key dimensions and key performance indicators (KPI) are defined. The predefined dimensions are market (segment), stakeholder, media sources and the internal dimension. As stakeholders, brand managers may consider customers, suppliers, collaborators, and partners. Customers might be divided in the categories customer_current, customer_former, customer_prospective and customer_contact. Market segments could be market_segment_current or market_segment_prospective. The internal dimension could be divided into the categories, namely staff and processes. The staff dimension could be divided in staff_management and staff_sales_service. Media sources could be media_sources_current or media_sources_prospective, media_sources_advertisements, and media_sources_sponsoring. In level 2, the relationship between dimensions and categories are defined. For each dimension all sub-dimensions are considered and the relationship to the other dimensions and sub dimensions are designed. In level 3, a detailed impact analysis can be conducted focusing on a master_brand to sub_brand relationship. In level 4 for each dimension a detailed impact analysis can be done (having no master brand all brands are treated equally at the same level).

\section{References}

Abdullah, L., \& Hasliza, A. (2011). Factor analysis Evidence in describing Consumer preferences for a soft drink product in Malaysia. Journal of Applied Sciences, 11(1), 139-144.

Bagozzi, R., \& Dholakia, U. (2002). Intentional social action in virtual communities. Journal of Interactive Marketing, 16(2), $2-21$.

Blanchard, A. L., \& Markus, M. L. (2004). The experienced 'sense’ of a virtual community: Characteristics and processes'. The Database for Advances in Information Systems, 35(1), 64-79.

Burke, K. (2006). Network to drive revenue. Target Marketing, 29(2), 25-26.

Czinkota, M., \& Ronkainen I. (2007). International marketing ( $8^{\text {th }}$ ed.). Mason, Ohio: Thomson- South Western.

De Moor, A., \& Weigand, H. (2007). Formalizing the evolution of virtual communities. Information Systems, 32(2), 223247.

Duduciuc, A., \& Ivan, L. (2014). Brand naming: Sound symbolism, brand preference and Brand Performance. Studies \& Scientific Researches: Economics Edition, 20, 169-176.

Erkollar, A., \& Oberer, B. (2010). Global branded E-Government stakeholder interaction. Proceedings of the INSITE 2010. Proceedings of the Informing Science Institute, Southern Italy.

Erkollar, A., \& Oberer, B. (2013a). How can brand managers benefit from social media? The social media management scorecard for brands (SMMS-B). International Journal of Business \& Management Studies, 5(1), 11-20. 
Erkollar, A., \& Oberer, B. (2013b). Keeping brands moving- Putting social media to the test: How the FMCG industry uses social networks for creating brand awareness. AWER Procedia Information Technology \& Computer Sciences, 3, 922-933.

Ferreira, M. P., \& Armagan, S. (2011). Using social network theory as a complementary perspective to the study of organizational change. Brazilian Administration Review, 8(2), 168-184.

Gammelgaar, J. (2010). Knowledge retrieval through virtual communities of practice. Behaviour \& Information Technology, 29(4), 349-362.

Ghachem, L. (2011). Online branding in newspapers: A conceptual model. Communications of the IBIMA, 2011(2011), 1-7.

Goncharuk, A. (2011). Making the mechanism of enterprise performance management. Economia: Seria Management, 14(1), $58-72$.

Grigore, A., Florica, B., \& Catalina R. (2010). Modern instruments for measuring organizational performance. Annals of the University of Oradea: Economic Science, 1(2), 951-956.

Izadi Manesh, F., \& Hozouri, S. (2013). An investigation of the role of brand image on consumer loyalty. Management Science Letters, 3(11), 2699-2704

Khraim, H. S. (2011). The influence of brand loyalty on cosmetics buying behavior of UAE female customers. International Journal of Marketing Studies, 3(2), 123-133.

Kotler, P. (1994). Marketing management: Analysis, planning, implementation, and control. Englewood Cliffs, NJ: PrenticeHall International.

Lakeworth, S. (2008). How important is branding to your marketing strategy? Boston: ASYSS.

Lefebvre, R. C. (2007). The new technology: The consumer as participant rather than target audience. Social Marketing Quarterly, 13(3), 31-42.

Mao, J. (2010). Consumer brand loyalty. International Journal of Business \& Management, 5(7), 213-217.

McDonald, M., de Chernatony, L., \& Harris, F. (2001). Corporate marketing and service brands: Moving beyond the fastmoving consumer goods model. European Journal of Marketing, 35(3/4), 335-346.

Mohmed, M. Y., \& Rahman A. (2010). The impact of social network on some selected corporate business. International Journal of Engineering Science \& Technology, 2(10), 5245-5254.

Moisescu O. (2009). The importance of brand awareness in consumers' buying decision and perceived risk assessment. Management \& Marketing, 7(1), 103-110.

Mousavi, S., Far, V., Shahrokh, Z., \& Taghavifard, S. (2013). An integrated model for building brand in food industry. Management Science Letters, 3, 2983-2988.

Stobbe, A., \& Jüch, C. (2005). Blogs: The new magic formula for corporate communications? Deutsche Bank Research, 53, $1-7$.

Story, J., \& Hess, J. (2010). Ethical brand management: Customer relationships and ethical duties. Journal of Product \& Brand Management, 19(4), 240-249.

Wong, H. Y., \& Merrilees, B. (2008). The performance benefits of being brand-orientated. Journal of Product \& Brand Management, 17(6), 372-383. 